\title{
ORGANIZACJA I FUNKCJONOWANIE WOJEWÓDZKIEGO TRANSPORTU KOLEJOWEGO NA PRZYKŁADZIE ŁÓDZKIEJ KOLEI AGLOMERACYJNEJ
}

\section{Abstract \\ Organisation and functioning of provincial railway transport on the example of Łódzka Kolej Aglomeracyjna}

Management is a process that is characteristic of every organization. It plays a special role in organizations dealing with public transport due to the complexity of conditions and the special economic and social role of the organization. This article deals with the management, organization and functioning of the railway sector, with particular emphasis on its functioning at the level of the voivodeship (region). The considerations are based on the example of the Łódź Province and transport within the Łódź agglomeration.

Keywords: railway transport, rail management, railway operation and organization, agglomeration railway

\section{Streszczenie}

Zarządzanie jest procesem znamiennym dla każdej organizacji. Szczególną rolę odgrywa w organizacjach zajmujących się transportem zbiorowym, które cechuje złożoność uwarunkowań i szczególna rola ekonomiczno-społeczna. W niniejszym artykule podjęto tematykę zarządzania, organizowania i funkcjonowania sektora kolejowego, w szczególności na poziomie województwa. Rozważania oparto na przykładzie województwa łódzkiego i transportu w ramach aglomeracji łódzkiej.

Słowa kluczowe: transport kolejowy, zarządzanie koleją, funkcjonowanie i organizacja kolei, kolej aglomeracyjna 


\section{Wstęp}

Codzienna rzeczywistość wymaga od nas przemieszczania się między różnymi punktami. Od czasu drugiej rewolucji przemysłowej, której zawdzięczamy zróżnicowanie środków transportu - w tym między innymi elektryczne tramwaje czy samochody z silnikiem elektrycznym - sposoby przemieszczania się ulegały zmianom. Zwiększające się potrzeby transportowe wymusiły powstanie publicznego transportu zbiorowego. Transport publiczny - w zależności od obsługiwanego obszaru - możemy podzielić na lokalny, miejski, aglomeracyjny, wojewódzki itp. Zgodnie z art. 4 ust. 14 ustawy z dnia 16 grudnia 2010 roku o publicznym transporcie zbiorowym (Dz.U. 2018, poz. 2016) za transport zbiorowy uznaje się powszechnie dostępny, regularny przewóz osób wykonywany w określonych odstępach czasu i po określonej linii lub sieci komunikacyjnej.

Ważnym aspektem jest pojmowanie transportu zbiorowego jako dobra publicznego. Według Tadeusza Markowskiego dobro publiczne to takie, które nie ulega wyłączeniu z konsumpcji, nie jest konkurencyjne i jest dostarczane nabywcom nieodpłatnie lub nieekwiwalentnie [Markowski, 1999: 67-68]. Transport publiczny należy rozumieć jako dobro publiczne, ponieważ zgodnie z przytoczoną definicją ma on zaspokajać potrzeby transportowe danej społeczności i nie stwarzać sytuacji wykluczenia lub konkurencyjności, co leży w gestii jednostek terytorialnych. Warunkiem zakwalifikowania przewozu jako publicznego jest więc powszechna dostępność [Kubalski i in., 1968: 9].

Z kolei według Jana Podolskiego transport zbiorowy spełnia swoje definicyjne zależności wyłącznie, jeżeli pojazdy świadczące przewozy są dostępne dla każdego, kto respektuje wewnętrzne regulacje świadczenia usług przewozowych na danym terenie, oraz jeżeli pojazdy kursują według rozkładu jazdy po niezmiennych trasach, zatrzymując się na wskazanych w rozkładzie jazdy przystankach [Podolski, 1985: 122-123].

Transport jest ważnym instrumentem integrującym daną społeczność. Między różnorodnymi ośrodkami istnieje istotna „więź” polegająca na wymianie osób i ładunków. Potrzeby przewozowe wynikają z mocno zróżnicowanych celów.

Publiczny transport zbiorowy jest systemem wieloskładnikowym, którego jednym z podsystemów jest kolej aglomeracyjna. W definiowaniu kolei aglomeracyjnej ważnym aspektem jest oddzielenie jej od kolei regionalnej. Region to:

najwyższa jednostka terytorialna organizacji w państwie, bez względu na formę prawnoustrojową, o relatywnie dużej powierzchni i znacznej liczbie ludności, jednolita z punktu widzenia gospodarczego, społecznego i kulturalnego, w której jest prowadzona odpowiednia do potrzeb polityka gospodarcza, społeczna i kulturalna przez powołane do tego instytucje regionalne [Elżanowski i in., 1990].

W warunkach polskich z pojęciem regionu utożsamiamy poziom wojewódzki. Aglomeracją z kolei nazwiemy ,zespół silnie zintegrowanych jednostek osadniczych skoncentrowanych wokół jednego lub kilku ośrodków, zamieszkany przez 
duże skupiska ludności” [Ekologia.pl, 2021]. Z konfrontacji obu pojęć wynika, że w systemach aglomeracyjnych więzi między jednostkami są silniejsze, aniżeli w regionie. Urząd Transportu Kolejowego charakteryzuje przewozy aglomeracyjne jako przewozy, które „mają na celu zaspokajanie potrzeb transportowych dużego ośrodka miejskiego/konurbacji/obszaru metropolitalnego, jak również potrzeb transportowych pomiędzy takim ośrodkiem i sąsiednimi obszarami” [UTK, 2014], czyli kolej aglomeracyjna służy przede wszystkim mieszkańcom aglomeracji, dojeżdżającym do większego ośrodka miejskiego. Natomiast przewozy regionalne mają w dużej mierze zaspokoić potrzeby przewozowe regionu (zob. tabela 1).

Tabela 1

Różnice między koleją aglomeracyjną a koleją regionalną

\begin{tabular}{|l|l|l|}
\hline \multicolumn{1}{|c|}{ Kolej aglomeracyjna } & \multicolumn{1}{c|}{ Kolej regionalna } \\
\hline $\begin{array}{l}\text { Częstotliwość kursowania } \\
\text { pociągów }\end{array}$ & Minimum 4 pociągi na godzinę & $\begin{array}{l}\text { Zazwyczaj mniej niż 4 pociągi na } \\
\text { godzinę }\end{array}$ \\
\hline $\begin{array}{l}\text { Odległość między } \\
\text { przystankami/stacjami }\end{array}$ & $\begin{array}{l}\text { Relatywnie niewielka (pociągi } \\
\text { zatrzymują się na każdej stacji) }\end{array}$ & $\begin{array}{l}\text { Większa niż w przypadku kolei } \\
\text { aglomeracyjnej (pociągi pomijają } \\
\text { niektóre stacje) }\end{array}$ \\
\hline Postoje & Wszystkie stacje i przystanki & $\begin{array}{l}\text { Przystanki i stacje osobowe } \\
\text { o większej wymianie pasażerskiej }\end{array}$ \\
\hline Finansowanie & Dotacje & Dotacje \\
\hline Organizator & Samorządy gmin i powiatów & Samorząd województwa \\
\hline Przykład & $\begin{array}{l}\text { Szybka Kolej Miejska } \\
\text { w Warszawie }\end{array}$ & $\begin{array}{l}\text { Koleje Dolnośląskie, Lódzka Kolej } \\
\text { Aglomeracyjna }\end{array}$ \\
\hline
\end{tabular}

Źródło: UTK, 2014.

Powszechnie wiadomo, że dla aglomeracyjnych i regionalnych przewozów kolejowych wspólne jest przede wszystkim konkurowanie z indywidualnym transportem samochodowym. Wzrost konkurencyjności transportu kolejowego nad innymi segmentami transportowymi wynika z wielu elementów - dotyczących zarówno zarządzania, jak i organizowania czy funkcjonowania tej formy transportu.

W założeniu transport kolejowy ma stanowić alternatywę wobec przemieszczania się transportem indywidualnym lub prywatnym. Jednakże - aby kolej stanowiła o sile swojej konkurencyjności w stosunku do innych form transportu musi być ciągle udoskonalana przez odpowiednie formy zarządcze, organizacyjne i planistyczne. Postulat ciągłego rozwoju przyczynił się do sformułowania pytania badawczego: jaki jest wpływ metod zarządzania - ze szczególnym uwzględnieniem organizowania i planowania - na satysfakcję podróżnych, a tym samym, jakie aspekty funkcjonowania kolei są najistotniejsze z punktu widzenia podróżnych, a także, czy podejmowanie odpowiednich działań związanych z zarządzaniem, 
organizowaniem i planowaniem przyczynia się do zwiększenia jakości świadczonych usług oraz podniesienia satysfakcji klientów. Weryfikacja tak przedstawionego zagadnienia stanowi główny cel artykułu. Będzie się ona koncentrować na analizie współcześnie stosowanych metod zarządzania, organizowania i planowania w kolejnictwie oraz na analizie praktycznego zastosowania przedstawionych metod na podstawie działań Łódzkiej Kolei Aglomeracyjnej (dalej: ŁKA). Efektem będzie prezentacja danych zgromadzonych w ramach przeprowadzonej ankiety satysfakcji podróżnych z usług świadczonych przez ŁKA.

\section{Metodologia i źródła badania}

Analizę stosowanych współcześnie metod zarządczych, organizacyjnych i planistycznych oparto na badaniu satysfakcji klienta z usług świadczonych przez ŁKA. Badający sprawdza, czy podejmowane działania zarządcze przekładają się na wzrost satysfakcji podróżnych, a tym samym, jakie aspekty funkcjonowania kolei aglomeracyjnej są najistotniejsze z punktu widzenia pasażerów. Podczas badania wzięto pod uwagę dziesięć zmiennych: częstotliwość korzystania z przewozów kolejowych, cel podróży, stację początkową i stację końcową, odległość miejsca zamieszkania od stacji początkowej, dostępność stacji początkowej (skomunikowanie za pomocą linii dowożących do przystanków), zalety oraz wady świadczonych usług, dostępność i przejrzystość informacji pasażerskiej, ofertę siatki połączeń oraz taryfę biletową.

Analizę powyższych czynników przeprowadzono wśród pasażerów jeżdżących na trasie kolejowej między Łodzią a miejscowościami Bedoń i Justynów. Wybór tej relacji wynika z ponad $100 \%$ wzrostu zainteresowania przejazdami kolejowymi tej relacji w 2018 roku względem roku poprzedniego. Badanie przeprowadzono $\mathrm{w}$ formie ankiety zdalnej (forma wynikająca $\mathrm{z}$ trudnej sytuacji sanitarno-epidemiologicznej).

\section{Organizacja transportu kolejowego wobec zaspokojenia potrzeb współczesnego pasażera}

Od czasu pierwszej rewolucji przemysłowej technologia zmienia się coraz szybciej. Firmy ze wszystkich branż, w tym również transportowe, są zmuszone do coraz szybszych i częstszych zmian technologicznych. Proces ten nie ominął również polskiego kolejnictwa, które wdraża liczne systemy usprawniające pracę oraz planowanie i organizowanie przewozów. Wiele uwarunkowań, w których funkcjonuje współczesna kolej, stanowi dla niej złożony proces decyzyjny. „Zarządca infrastruktury musi skoordynować własne możliwości z wymaganiami przewozów kolejowych" [Jacyna M., Gołębiewski P., Krześniak M., Szkopiński J., 2019, 100]. Aby realizacja i organizacja przewozów kolejowych była optymalna, należy skoordynować procesy przedstawione na rysunku 1. 


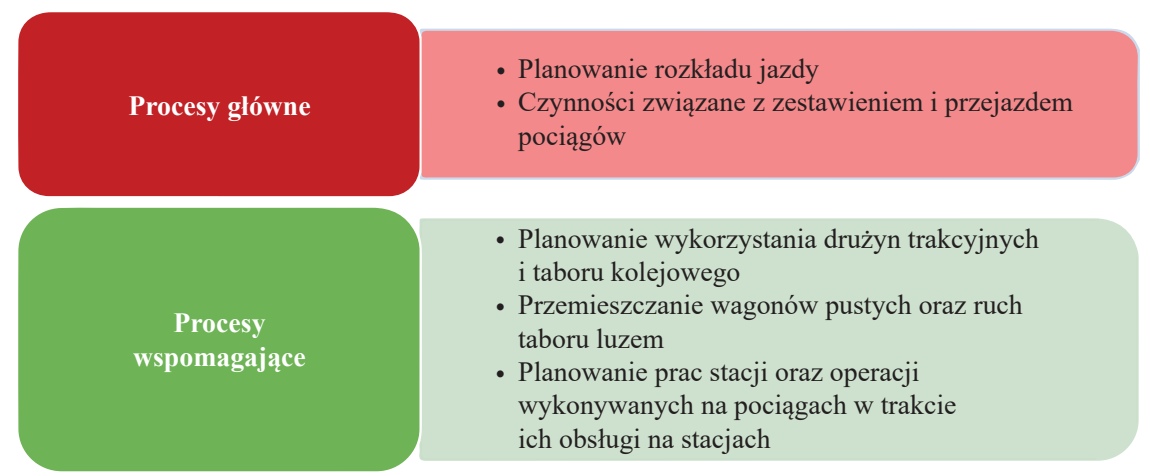

Rysunek 1. Procesy organizacji i koordynacji kolei

Źródło: Jacyna i in., 2019: 100.

Proces planowania rozkładów jazdy oraz czynności związane z zestawieniem i przejazdem pociągów są skomplikowanym ciągiem decyzyjnym niosącym ze sobą dużą odpowiedzialność. Rozkład jazdy może być przygotowywany dla wybranej linii lub danego obszaru (na przykład aglomeracji). Na podstawie Organizacji ruchu kolejowego [Jacyna i in., 2019] można zaprezentować sposób konstruowania rozkładu jazdy pociągów. Proces ten rozpoczyna się od kształtowania oferty przewozowej, czyli wyznaczania przebiegu linii, przydziału składów pociągowych, częstotliwości kursowania oraz wielkości potoku obsługiwanego przez daną linię komunikacyjną. Kolejnym etapem jest wygenerowanie wykresów obrazujących ruch pociągów, dzięki czemu wyznaczane zostają wzorcowe trasy. Likwiduje się kolizje pociągów na szlaku - jest to ważne w przypadku odcinków jednotorowych. Tworzenie rozkładu jazdy pociągów jest istotnym procesem szczególnie w przypadku dużych obszarów o wzmożonym ruchu kolejowym. Popełnienie błędu przy konstruowaniu rozkładu może mieć druzgocące konsekwencje. Podczas prac konstrukcyjnych należy pamiętać również o innych aspektach towarzyszących ruchowi kolejowemu, takich jak: prowadzone prace remontowe, długość i dostosowanie peronów do składów, dostępność taborowa przewoźnika, ograniczenia prędkości, liczba przejazdów kolejowych i innych kolizji (przejścia dla pieszych, kładki, tunele) oraz - przede wszystkim - należy pamiętać o zapewnieniu przepustowości linii. Przepustowość kolejowa to „maksymalna liczba pociągów (...), która może w sposób płynny przejechać po analizowanej linii kolejowej w ciągu określonego czasu - zazwyczaj doby" [Jacyna i in., 2019: 142]. O przepustowości linii decyduje wiele czynników, w tym między innymi maksymalna prędkość, zaplecze techniczne trasy (zastosowane technologie, sposób ułożenia szyn) oraz rodzaj taboru kursującego po danej linii kolejowej. W świetle niniejszej pracy istotny jest wskaźnik przepustowości dla ruchu pasażerskiego podmiejskiego. Według Międzynarodowego Związku Kolei (International Union of Railways, dalej: UIC) przeciążenie linii kolejowej w godzinach szczytu nie powinno przekraczać $85 \%$ 
przepustowości, a w pozostałych godzinach -70\% [UIC, 2013]. Wynika to przede wszystkim z racji stworzenia pewnej rezerwy, która w sytuacjach losowych (na przykład awaria pociągu, wykolejenie, brak zasilania, wypadek) pozwoli na racjonalne działania, tak aby ruch pociągów mógł odbywać się w miarę bezproblemowo z zapewnieniem bezpieczeństwa.

W zarządzaniu koleją i konstruowaniu rozkładu jazdy istotne jest posiadanie wiedzy na temat potrzeb przewozowych na danych liniach. Aby uzyskane dane były jak najbardziej adekwatne do rzeczywistości, proces opracowywania potrzeb przewozowych należy rozpocząć od przeprowadzenia badań podróży, czyli

umotywowanego przemieszczenia się osoby pieszo lub z wykorzystaniem jednego lub więcej przejazdów środkami transportu pomiędzy określonymi jako źródło i cel podróży miejscami, z których każdemu da się przypisać [...] motywację [Krych, Kaczkowski, 2010].

Efektem przeprowadzonych badań są dane na temat kierunków podróży oraz godzin ich odbywania, motywacji podróży, średni czas podróży, preferowany czas korzystania $\mathrm{z}$ usług. Zebrane dane stanowią podstawę do opracowania modelu przemieszczania się podróżnych, czyli więźby ruchu (rysunek 3) lub w przypadku bardziej szczegółowych badań, do skonstruowania przestrzennego rozmieszczenie potoków pasażerskich (rysunek 2).

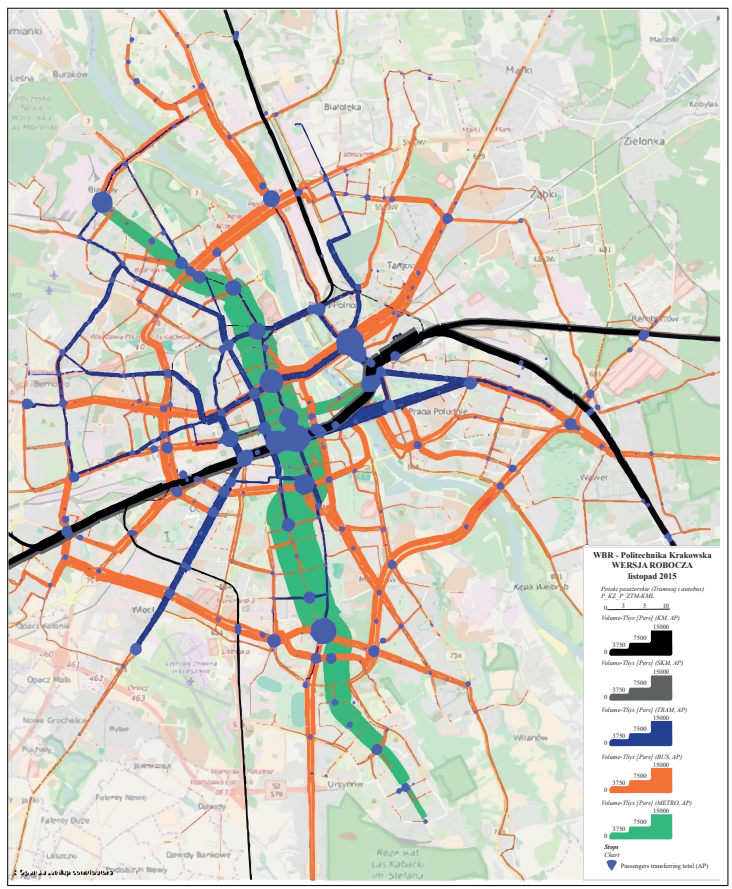

Rysunek 2. Procesy organizacji i koordynacji kolei

Źródło: Jacyna i in., 2019: 100. 


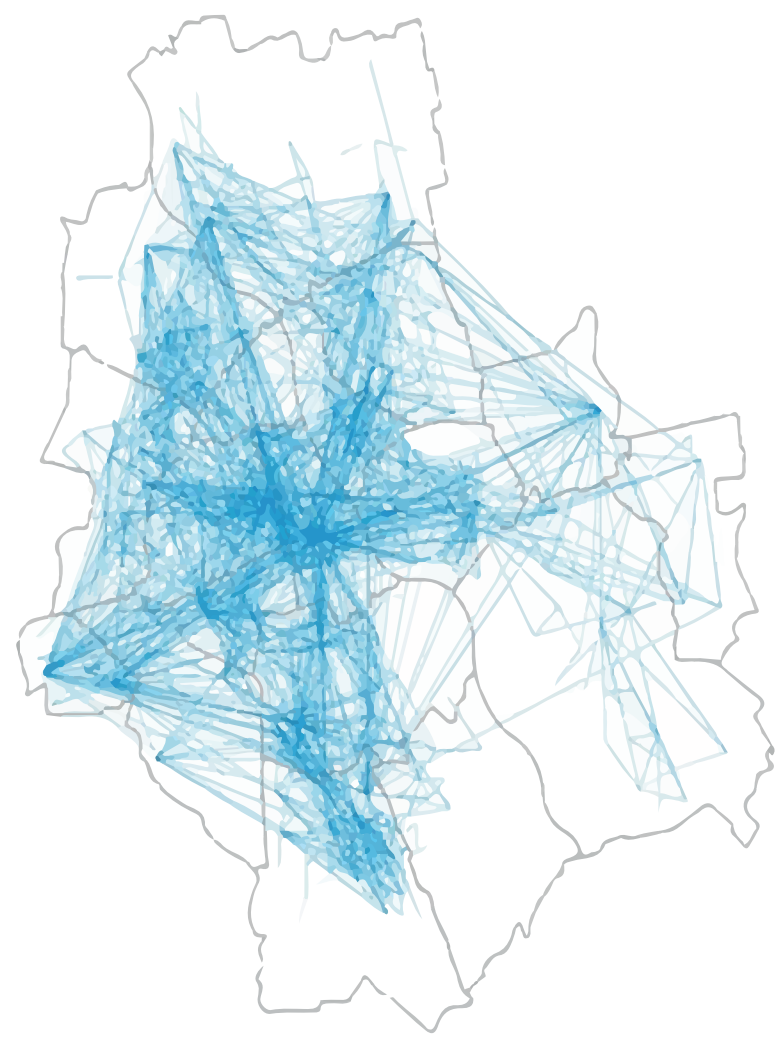

Rysunek 3. Więźba podróży

Źródło: Wyniki WBR 2015, 2016.

Przy opracowywaniu potrzeb transportowych należy mieć na uwadze odpowiednie mierniki ruchu pasażerskiego. W zarządzaniu ruchem kolejowym wyróżniamy dwie grupy mierników: przewozowe i eksploatacyjne [Krzemieniecki, Tarantowicz, 1975]. Pod hasłem mierników przewozowych znajdują się między innymi: liczba podróżnych, wozokilometry, liczba sprzedanych biletów, kategoria linii (regionalna, krajowa, międzynarodowa itp.). W grupie mierników eksploatacyjnych znajdują się wartości związane z eksploatacją infrastruktury kolejowej (szyn, trakcji, rozjazdów) oraz eksploatacją pociągów (przebieg i czas pracy lokomotyw, wagonów). Wykorzystanie mierników pozwala na dokładniejsze opracowanie potrzeb przewozowych. Należy jednak pamiętać, że określanie potrzeb przewozowych nie może być procesem jednorazowym, lecz dokonywanym systematycznie. Cykliczne opracowywanie zapotrzebowania na przewozy pozwala na racjonalne dysponowanie środkami finansowymi, lepsze wykorzystanie parku taborowego oraz określa, jakie inwestycje są konieczne, aby podwyższyć poziom oferowanych usług. 
Kolejnym aspektem istotnym w zarządzaniu siecią kolejową jest obsługa drużyn trakcyjnych oraz obieg pojazdów trakcyjnych. Każdy pojazd jest przypisany do konkretnej bazy, w której jest serwisowany. Aktualnie pojazd trakcyjny jest obsługiwany przez drużynę zmienną, a nie drużynę trakcyjną. Skutkuje to efektywniejszym wykorzystaniem zasobów, gdyż po skończonej pracy pierwszej drużyny pojazd nie musi zjeżdżać do bazy, a przejmuje go druga drużyna. Pozwala to między innymi na zachowanie pewnej rezerwy taborowej, nie ma konieczności wysyłania $100 \%$ parku taborowego do obsługi linii. W skład drużyny pociągowych wchodzi kierownik pociągu, drużyna konduktorska oraz maszynista. Drużynę pociągu może stanowić również sam kierownik z maszynistą. Przy zarządzaniu koleją, a w szczególności opracowywaniu rozkładów jazdy należy mieć na uwadze maksymalny czas pracy drużyn pociągowych wynoszący 8 godzin dziennie, a więc 40 godzin tygodniowo (zob. art. 129 ustawy z dnia 26 czerwca 1974 roku - Kodeks pracy, t.j. Dz.U. 2020, poz. 1320 ze zm.).

Oprócz wspomnianych wyzwań stawianych przed organizatorami transportu kolejowego należy pamiętać również o zapewnieniu odpowiedniej dystrybucji biletów oraz odpowiednio dostosowanego do potrzeb pasażerów taboru (w tym jego wielkości), stworzeniu własnego zaplecza technicznego umożliwiającego serwisowanie i bieżące naprawy posiadanego taboru, gwarancji wysokiego poziomu satysfakcji pasażerów, a także o zapewnieniu wystarczającej liczby odpowiednio wykwalifikowanych pracowników. Celem tych wszystkich działań jest jak najszersze pozyskanie klientów oraz zyskanie ich lojalności.

Proces zarządzania koleją jest długotrwałym, czasochłonnym, kapitałochłonnym i skomplikowanym zadaniem. Ułożenie odpowiednich tras, rozkładów jazdy, grafików pracy oraz przydział taborowy często zajmuje miesiące (rozkłady jazdy dla sieci ogólnopolskiej są konsultowane nawet rok przed ich wprowadzeniem).

\section{Funkcjonowanie Łódzkiej Kolei Aglomeracyjnej}

Łódzka Kolej Aglomeracyjna jest spółką należącą do Samorządu Województwa Łódzkiego. Głównym jej celem jest realizowanie art. 14 ustawy z dnia 5 czerwca 1998 roku o samorządzie województwa (t.j. Dz.U. 2020, poz. 1668) z zakresu gospodarki komunalnej o charakterze użyteczności publicznej, tj. „bieżące i nieprzerwane zaspokajanie zbiorowych potrzeb ludności w drodze świadczenia usług powszechnie dostępnych”. Spółka wykonuje zadania o charakterze wojewódzkim w zakresie transportu zbiorowego oraz jego funkcjonowania.

Aktualnie trudno jest wyobrazić sobie poruszanie się po województwie łódzkim bez ŁKA. Spółka wpisała się w krajobraz województwa i zyskała szerokie grono klientów. Park taborowy spółki stanowi 20 elektrycznych zespołów trakcyjnych typu Stadler FLIRT3 oraz 14 elektrycznych zespołów trakcyjnych typu Newag Impuls 2. Cechą szczególną taboru należącego do ŁKA jest jego młody wiek, ponieważ wszystkie elektryczne zespoły trakcyjne (EZT) są fabrycznie nowe, a najstarsze pociągi mają 6 lat. Aby utrzymać jak najwyższy poziom świadczonych 
usług, spółka posiada własne zaplecze techniczne zlokalizowane na terenie stacji Łódź Widzew. Posiadanie we własnych strukturach takiego obiektu znacząco usprawnia funkcjonowanie spółki. Sercem wielotorowego zaplecza jest hala serwisowa $\mathrm{z}$ torami naprawczymi, myjnią oraz pomieszczeniami socjalnymi, dyspozytorami nastawni oraz magazynem. Każdy z torów przeglądowych wyposażony jest w kanał pozwalający na pracę pod pojazdem, dodatkowo w hali znajduje się tor z platformami umożliwiającymi pracę na dachu. W ramach bieżącej obsługi pojazdy są sprzątane i myte, uzupełnia się wodę i piasek w odpowiednich zbiornikach, a także odprowadza się fekalia.

Interesująca wydaje się szeroka gama biletów proponowanych przez ŁKA, która świadczyć może o elastyczności oferty. Oprócz biletów objętych podstawowymi zniżkami wynikającymi z ustawy z dnia 20 czerwca 1992 roku o uprawnieniach do ulgowych przejazdów środkami publicznego transportu zbiorowego (t.j. Dz.U. 2018, poz. 295) oraz ustawy z dnia 16 listopada 2006 roku o świadczeniu pieniężnym i uprawnieniach przysługujących cywilnym niewidomym ofiarom działań wojennych (t.j. Dz.U. 2020, poz. 684) znajdziemy miedzy innymi: bilety zintegrowane z Państwową Komunikacją Samochodową - ŁKA + PKS, bilety okresowe, bilety wycieczkowe czy Wspólny Bilet Aglomeracyjny (dalej WBA) ${ }^{1}$. Dodatkowo spółka wprowadza liczne oferty specjalne, jak na przykład wydłużenie biletów okresowych (bezterminowo) dla pracowników służby zdrowia w związku z epidemią COVID-19, wydłużenie strefy A w ofercie biletów strefowych do Bedonia i Justynowa w związku z remontem głównej drogi dojazdowej do tych miejscowości.

Przewoźnik dysponuje nowoczesnym taborem wyposażonym w bramki liczące pasażerów wsiadających i wysiadających na poszczególnych stacjach i przystankach. Urządzenia posiada każdy z 34 elektrycznych zespołów trakcyjnych, które są w dyspozycji spółki. Rozwiązanie stanowi podstawę Systemu Liczenia Pasażerów (dalej: SLP), za pomocą którego na bieżąco można sprawdzać frekwencję w pociągu znajdującym się na danej trasie. Raporty generowane z SLP pozwalają określić liczbę pasażerów wsiadających i wysiadających na danej stacji lub przystanku, a także liczbę osób przebywających w pociągu na danym odcinku. Dane $\mathrm{z}$ tego systemu:

- stanowią podstawę do obliczania potoków pasażerskich na liniach i ich odcinkach,

- umożliwiają właściwe dobranie taboru do liczby podróżnych (zmiana nawet w kolejnym dniu na większą lub mniejszą jednostkę, lub wprowadzenie podwójnej trakcji),

- dają możliwość identyfikacji pociągów pod względem generowanych potoków pasażerskich i modyfikowania ich rozkładu jazdy w kolejnych organizacjach ruchu w celu zoptymalizowania oferty przewozowej.

1 Wspólny Bilet Aglomeracyjny to bilet okresowy skierowany do osób korzystających z przejazdów komunikacją miejską na terenie Łodzi, Pabianic, Zgierza, Łasku, Zduńskiej Woli, Sieradza, Strykowa, Głowna i Łowicza oraz pociągami ŁKA i POLREGIO. 
Obecnie ŁKA - na potrzeby wewnętrznego i zewnętrznego raportowania gromadzi dane o potokach pasażerskich dla linii i odcinków (a także dla każdej stacji i każdego przystanku na poniższych liniach) przedstawionych w tabeli 2.

Tabela 2

Prowadzenie badań potoków pasażerskich na liniach obsługiwanych przez ŁKA

(stan na 29 czerwca 2020 roku)

\begin{tabular}{|c|c|}
\hline Nr linii kolejowej & Linia komunikacyjna \\
\hline \multirow[t]{2}{*}{14} & Łódź Kaliska - Sieradz \\
\hline & Łódź Kaliska - Łowicz Główny \\
\hline \multirow[t]{3}{*}{$15 ; 532$} & odcinek Łódź Kaliska - Zgierz \\
\hline & odcinek Zgierz - Łowicz \\
\hline & Łódź Kaliska - Kutno \\
\hline \multirow[t]{2}{*}{15,16} & odcinek Łódź Kaliska - Zgierz \\
\hline & odcinek Zgierz - Kutno \\
\hline 16 & Łódź Widzew - Zgierz \\
\hline $25 ; 540$ & Łódź Kaliska - Łódź Widzew \\
\hline \multirow[t]{2}{*}{17} & Łódź Fabryczna - Łódź Widzew \\
\hline & Łódź Widzew - Skierniewice - Warszawa Wsch. \\
\hline \multirow[t]{4}{*}{$1 ; 17$} & $\begin{array}{l}\text { odcinek Łódź Widzew - Koluszki } \\
\text { (tylko pociągi do Koluszek/Skierniewic/Warszawy Wschodniej) }\end{array}$ \\
\hline & odcinek Koluszki - Skierniewice \\
\hline & odcinek Skierniewice - Warszawa Wsch. \\
\hline & Łódź Widzew - Koluszki - Radomsko \\
\hline \multirow[t]{3}{*}{$1 ; 17 ;(538)$} & odcinek Łódź Widzew - Koluszki (tylko pociągi do/z Radomska) \\
\hline & odcinek Koluszki - Radomsko \\
\hline & Łódź Widzew - Koluszki - Tomaszów Mazowiecki \\
\hline \multirow[t]{2}{*}{$17 ; 25 ;(537) ;(534)$} & $\begin{array}{l}\text { odcinek Łódź Widzew - Koluszki } \\
\text { (tylko pociągi do/z Tomaszowa Mazowieckiego) }\end{array}$ \\
\hline & Skierniewice - Kutno \\
\hline \multirow[t]{2}{*}{$3 ; 11$} & odcinek Skierniewice - Łowicz \\
\hline & odcinek Łowicz - Kutno \\
\hline
\end{tabular}

Źródło: Łódzka Kolej Aglomeracyjna sp. z o.o.

Na podstawie danych o potokach pasażerskich dla linii komunikacyjnych i odcinków wyszczególnionych w tabeli 2 możliwe jest stworzenie graficznego obrazu wielkości ruchu pasażerskiego w Łodzi i województwie łódzkim (w wybranym przedziale czasu). 


\section{Badania na temat satysfakcji podróżnych z usług świadczonych przez Łódzką Kolej Aglomeracyjną na trasie Łódź-Justynów}

W badaniu wzięły udział 334 osoby. Wśród respondentów znalazło się 199 kobiet i 135 mężczyzn. Przewaga liczebna kobiet może wynikać z chętniejszego udziału w badaniu oraz wysokiego współczynnika feminizacji (119 kobiet na 100 mężczyzn dla miasta Łodzi oraz 111 kobiet na 100 mężczyzn dla gminy Andrespol) [BDL GUS, 2020]. Struktura wiekowa ankietowanych rozkłada się dość interesująco. Zdecydowanie dominującą grupą są osoby w wieku 19-26 lat. Z kolei najmniejszy udział respondentów odnotowany został w grupie 66+. Może to wynikać z formy przeprowadzania badania (online).

\section{Przedział wiekowy badanych}

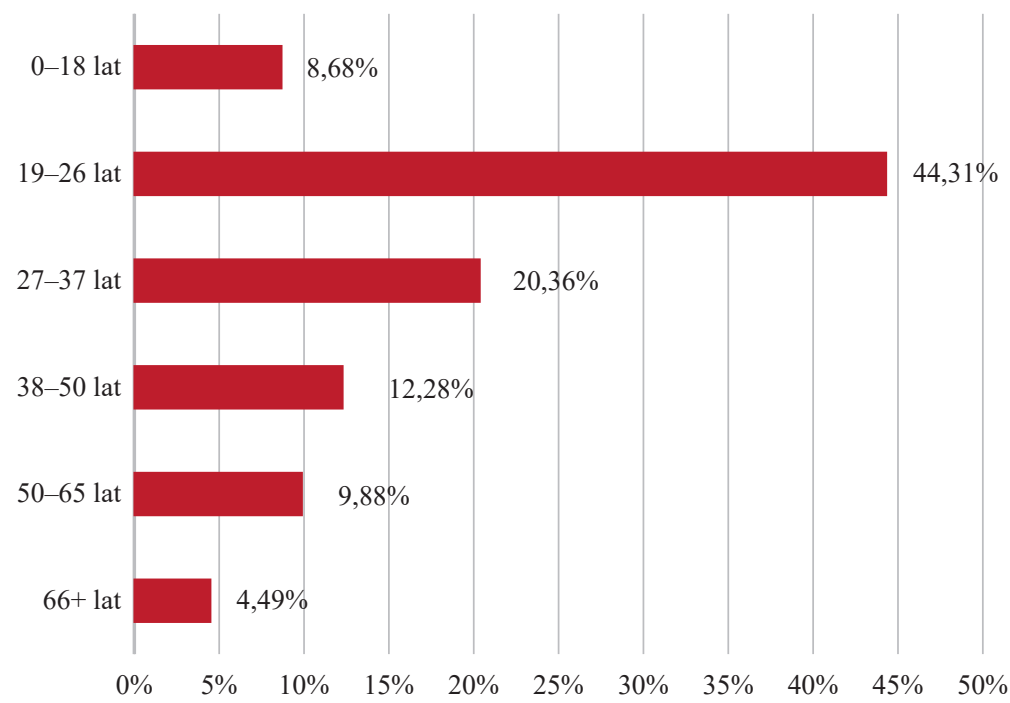

Wykres 1. Przedział wiekowy badanych

Źródło: opracowanie własne.

Przedział wiekowy częściowo pokrył się z przewidywanymi grupami społecznymi (wykres 2). Zdecydowana większość respondentów to pracownicy i studenci. Najmniejszą grupę badanych stanowią osoby bez pracy. 
Status badanych

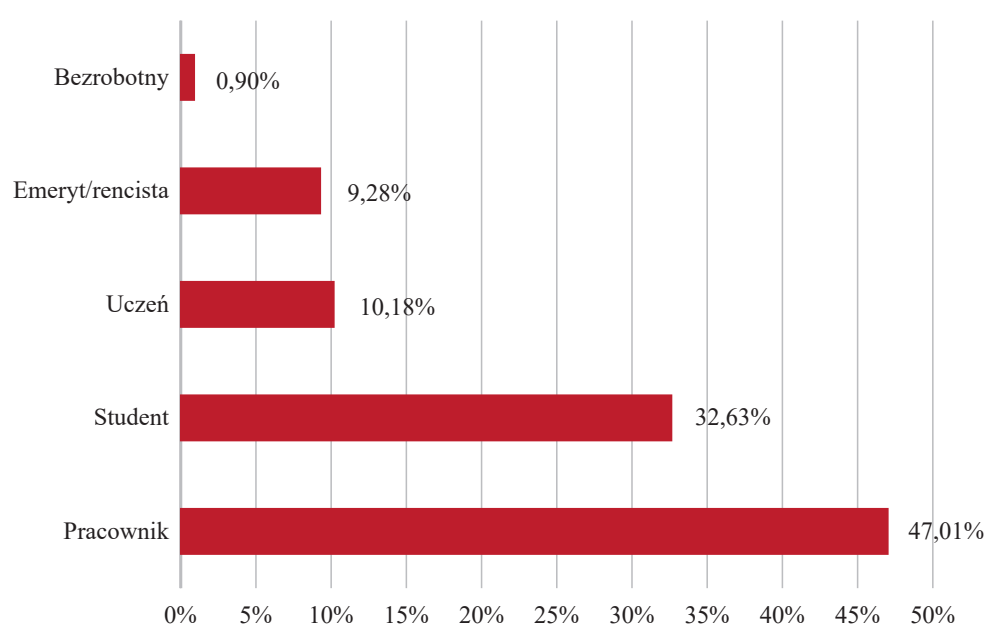

Wykres 2. Status badanych

Źródło: opracowanie własne.

Częstotliwość korzystania z przewozów na linii Łódź-Justynów

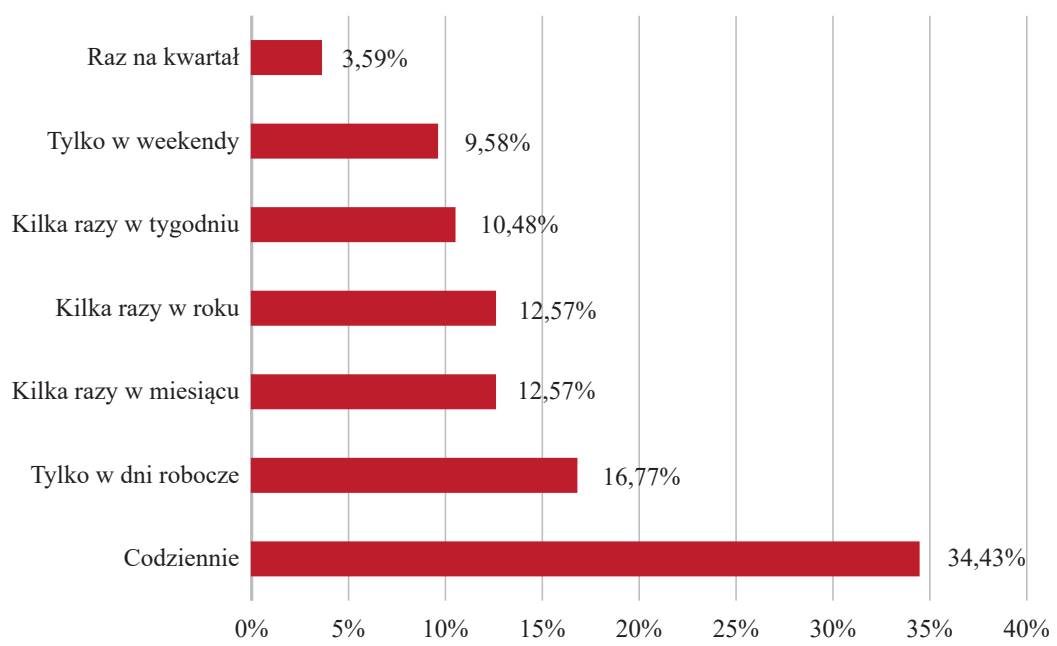

Wykres 3. Częstotliwość korzystania z przewozów na linii Łódź-Justynów

Źródło: opracowanie własne. 


\section{Cel podróży}

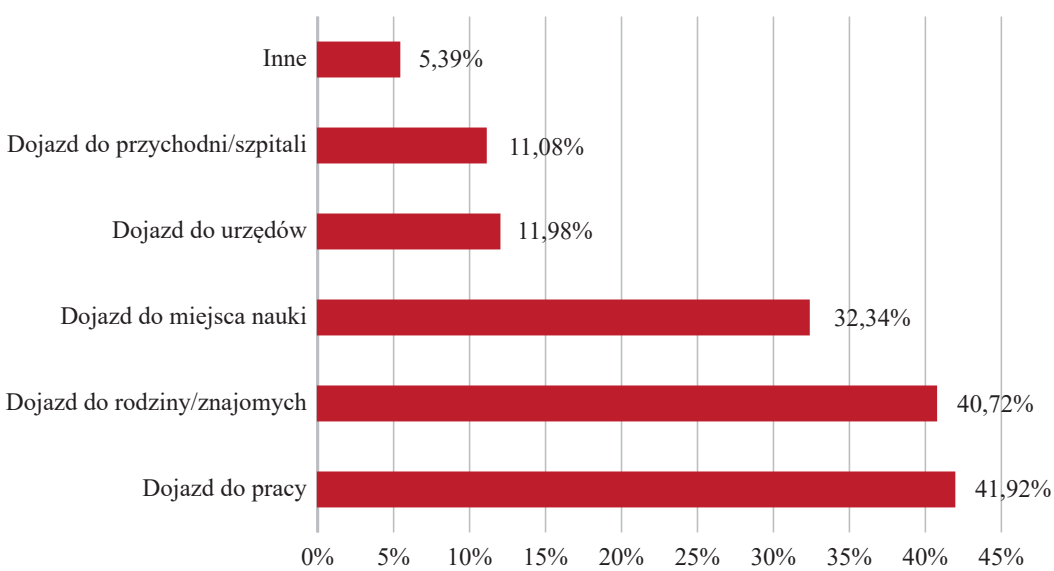

\section{Wykres 4. Cel podróży}

Źródło: opracowanie własne.

Popularność stacji/przystanków obsługiwnych przez ŁKA

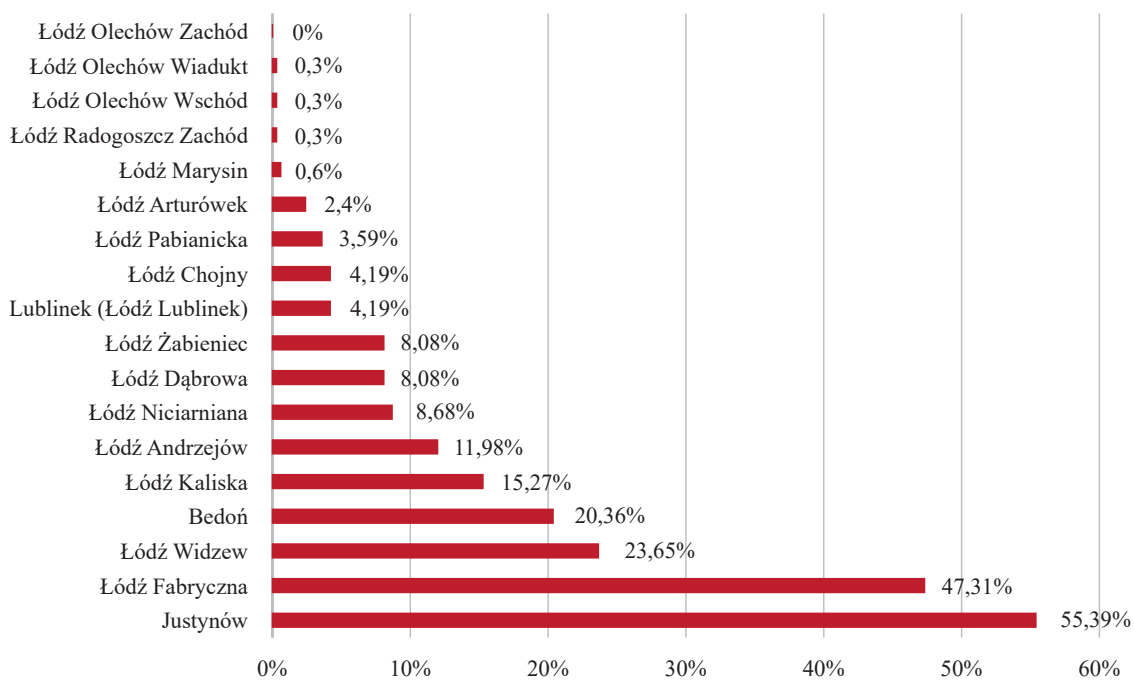

Wykres 5. Popularność stacji/przystanków kolejowych obsługiwanych przez ŁKA z możliwością dojechania do stacji Justynów

Źródło: opracowanie własne. 
Na wstępie badający chciał sprawdzić częstotliwość korzystania z usług ŁKA na trasie między Justynowem a Łodzią (wykres 3). Jak wynika ze zgromadzonych danych, największa liczba badanych korzysta z przewozów kolejowych na trasie Łódź-Justynów codziennie. Najmniejsza grupa badanych to pasażerowie korzystający z podróży kwartalnie.

Jak wynika z wykresu 4, największą część respondentów stanowią osoby dojeżdżające do pracy, niewiele mniejszą - osoby dojeżdżające do rodziny lub znajomych. Wyraźnie widać powiązanie częstotliwości kursowania z celem podróży. Respondenci podróżujący codziennie wykorzystują kolej jako środek transportu do miejsca pracy czy nauki. Osoby korzystające rzadziej niż codziennie i tylko $\mathrm{w}$ dni robocze korzystają $\mathrm{z}$ oferty przewozowej w celach rekreacyjnych, $\mathrm{w}$ sprawach urzędowych i zdrowotnych. Wśród odpowiedzi badanych pojawiły się również: dojazd do instytucji kultury, wyjazd w celach rekreacyjno-turystycznych.

Największą popularnością na terenie Łodzi cieszą się stacje centralne na trasie linii Łódź-Justynów, to jest Łódź Fabryczna i Łódź Widzew. Sporym zainteresowaniem - pomimo braku obsługi bezpośredniej ze stacjami Bedoń i Justynów cieszą się staje Łódź Kaliska, Łódź Żabieniec oraz Łódź Dąbrowa. Najmniejszym zainteresowaniem na trasie do Bedonia lub Justynowa cechują się stacje zlokalizowane na Olechowie, choć prawdopodobnie ich rola w przyszłości będzie rosła w związku z trwającą rozbudową powierzchni magazynowych w tamtej okolicy (wykres 5).

Większość pasażerów korzystających z przystanków w Justynowie lub Bedoniu mieszka w obrębie $500 \mathrm{~m}$ do $1 \mathrm{~km}$ od stacji (lub cel podróży znajduje się również w tym przedziale odległości od przystanku) (wykres 6). Oznacza to, że mieszkają oni w bliskiej odległości od przystanku, a dojście do niego nie powinno przekraczać 10 minut. Co ciekawe, najmniejsza liczba pasażerów mieszka w odległości mniejszej niż $500 \mathrm{~m}$. Znaczący odsetek badanych mieszka w odległości powyżej $2 \mathrm{~km}$ od przystanku. Oznacza to, że prawdopodobnie korzystają ze środków dojazdowych do stacji - rowerów, samochodów, autobusów.

Przypuszczenie co do korzystania z linii dowożących do przystanków ŁKA potwierdza liczba osób, które deklarują korzystanie z wymienionych form dojazdu do stacji (wykres 7). Tym samym pasażerowie - aby skorzystać z usług przewoźnika kolejowego - zmuszeni są do dojechania na stację linią komunikacji miejskiej, która w tym rejonie niemalże nie funkcjonuje lub jest nieskorelowana z godzinami odjazdów pociągów.

Pasażerowie korzystający z pociągów na badanej trasie za największy walor uważają wydłużenie biletu okresowego w strefie A do Justynowa, a następnie czas przejazdu, który do stacji Łódź Fabryczna wynosi 15 minut, podczas gdy samochodem taka podróż może trwać nawet 45 minut. Następnie należy wyróżnić ceny przejazdu oraz klimatyzowane pojazdy i punktualność. Wynika z tego, że pasażerów przede wszystkim przyciąga niska cena, jaką są zobowiązani uiścić za przejazd pociągiem oraz udogodnienia w postaci klimatyzacji (wykres 8). 
Odległość miejsca docelowego od przystanku ŁKA w Justynowie lub Bedoniu

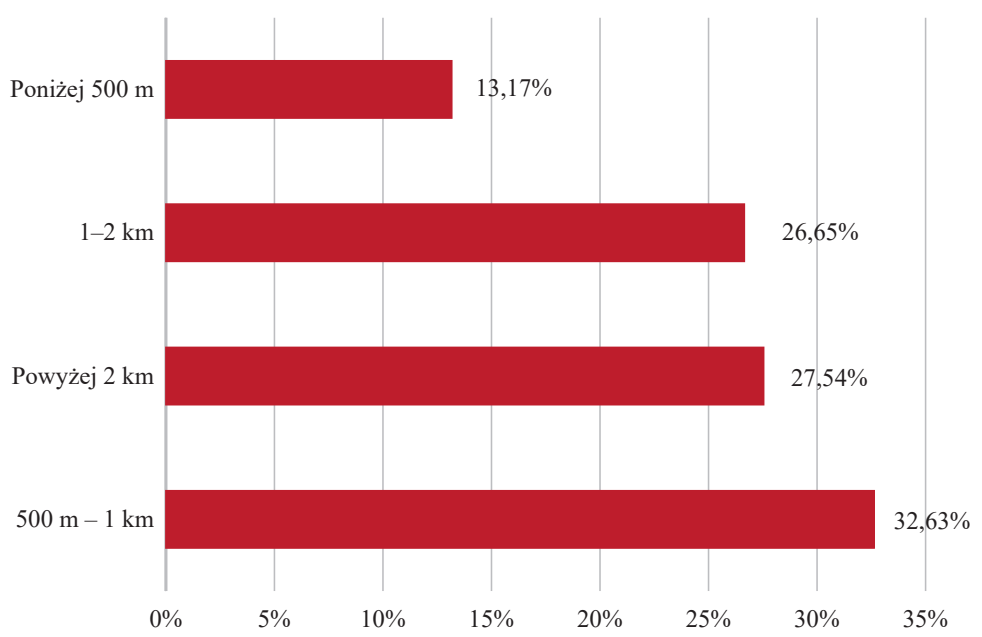

Wykres 6. Odległość od miejsca docelowego podróży do przystanku ŁKA w Justynowie lub Bedoniu

Źródło: opracowanie własne.

Odsetek osób deklarujących korzystanie z linii dowożących do przystanku ŁKA w Justynowie lub Bedoniu

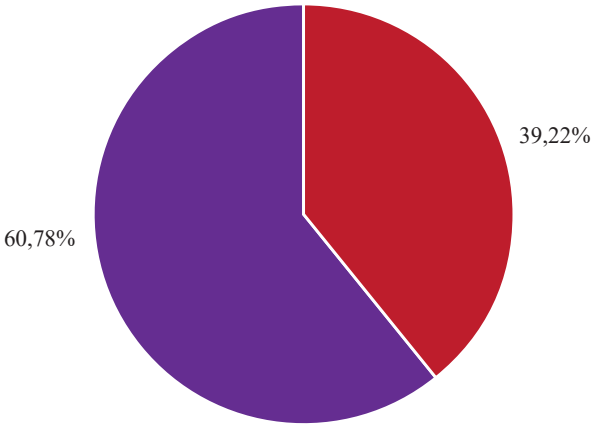

Tak

Nie

Wykres 7. Odsetek osób deklarujących korzystanie z linii dowożących do przystanku ŁKA w Justynowie lub Bedoniu

Źródło: opracowanie własne. 
Zalety ŁKA na trasie Łódź-Justynów

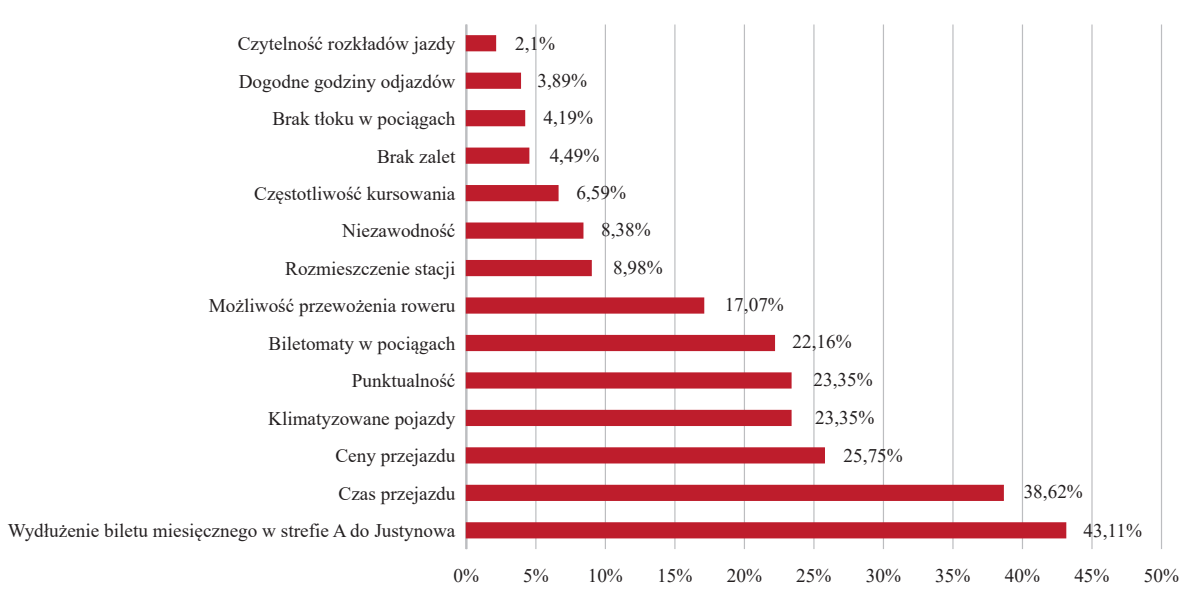

\section{Wykres 8. Zalety ŁKA na trasie Łódź-Justynów}

Źródło: opracowanie własne.

Wady ŁKA na trasie Łódź-Jutynów

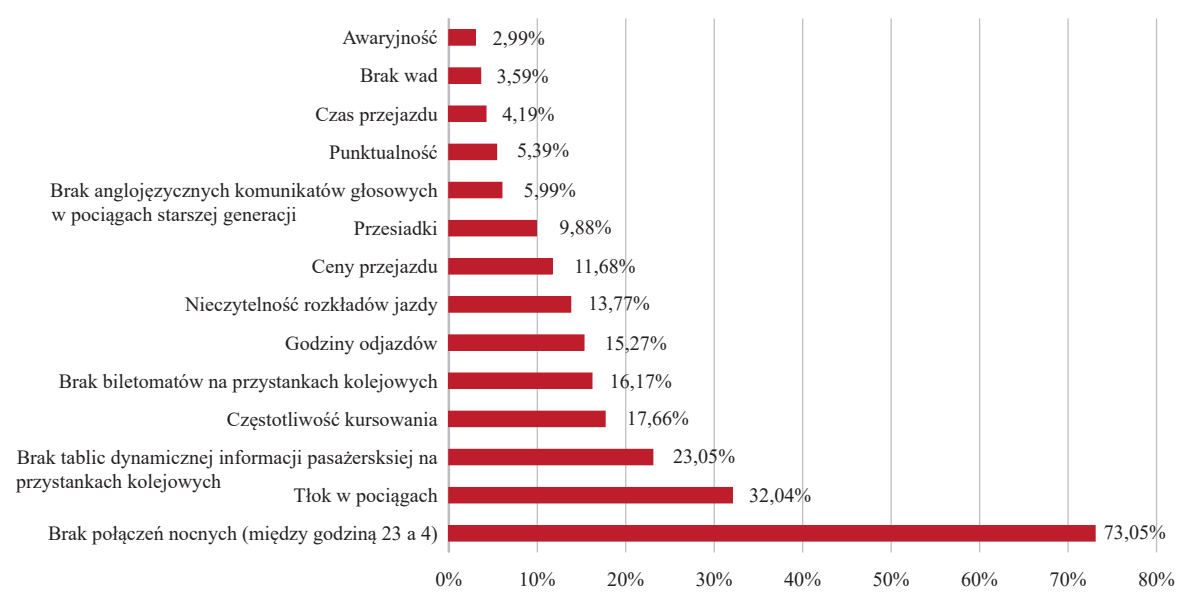

Wykres 9. Wady ŁKA na trasie Łódź-Justynów

Źródło: opracowanie własne. 
Źródła informacji na temat funkcjonowania $Ł K A$

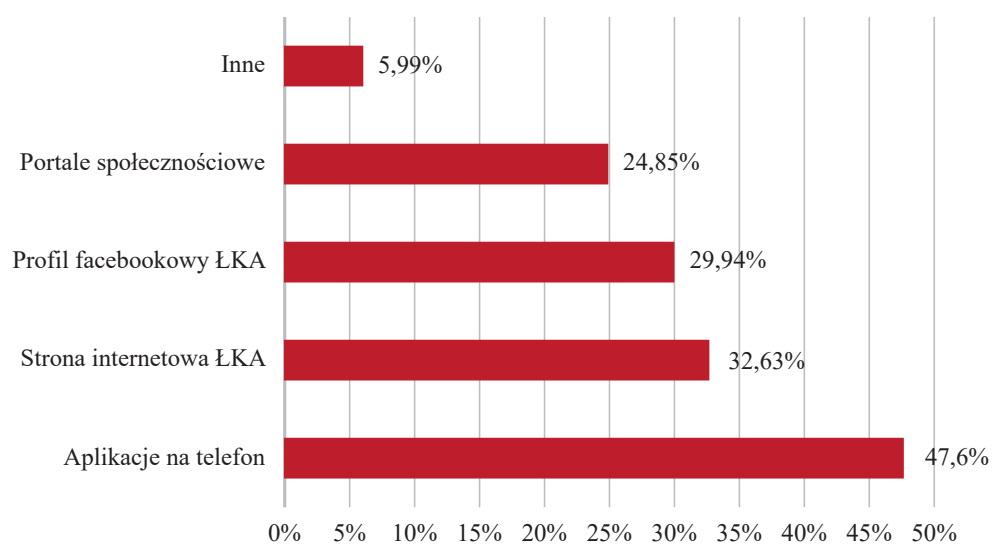

Wykres 10. Źródła informacji na temat funkcjonowania ŁKA

Źródło: opracowanie własne.

Ocena wystarczalności informacji pasażerskiej

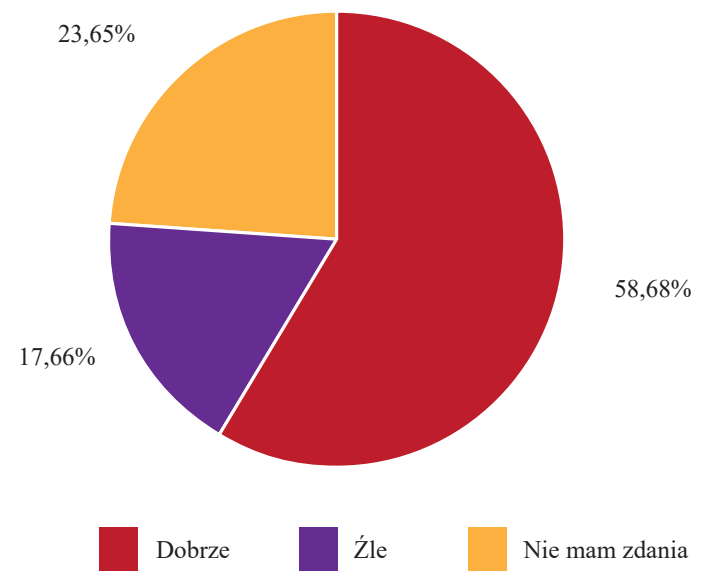

Wykres 11. Ocena wystarczalności informacji pasażerskiej ŁKA

Źródło: opracowanie własne. 
W przypadku wad ŁKA i zastosowanych przez nią rozwiązań na pierwsze miejsce wysuwa się brak połączeń nocnych (między 23:00 a 4:00). Dodatkowo blisko $18 \%$ badanych uważa, że rozkład jazdy jest źle skonstruowany. Poddając analizie stan na grudzień 2020 roku, należy zauważyć brak równego taktu między kursami. Wyraźne jest skumulowanie w krótkich odstępach czasu kilku kursów, po czym następuje nawet dwugodzinna przerwa. Przykładowo w dni robocze kurs w kierunku Łodzi odbywa się o godzinie 10:56, 11:01, 11:21, a kolejny dopiero o godzinie 13:01. Kolejną niedogodnością jest tłok w pociągach oraz brak tablic dynamicznej informacji pasażerskiej na przystankach kolejowych (wykres 9).

Największą popularnością wśród źródeł informacji pasażerskiej cieszą się aplikacje na telefon. Może to wynikać z przeważającej grupy wiekowej respondentów - 19-26 lat. Drugie miejsce zajęła strona internetowa przewoźnika oraz profil na portalu społecznościowym. Jak widać, największą popularnością cieszą się mobilne środki informacji, choć w kategorii „inne” pojawiły się też odpowiedzi: „telefonicznie”, „drogą pantoflową" lub „z ogłoszeń i rozkładów jazdy w formie stacjonarnej na stacjach" (wykres 10).

Widać wyraźnie, że największą bolączką pasażerów jest nieczy telność rozkładów jazdy, które znajdują się na przystankach ŁKA.

W przypadku oceny wystarczalności źródeł informacji pasażerskiej zdecydowana większość ankietowanych ocenią ją dobrze. Negatywny wynik wystawiło 59 ankietowanych, co świadczy o dobrej wystarczalności źródeł informacji pasażerskiej (wykres 11).

Dominująca liczba ankietowanych uważa, że zdecydowanie potrzebne jest w prowadzenie dodatkowej informacji o zmianie strefy taryfowej biletu WBA. Następną istotną z punktu widzenia podróżujących zmianą jest wprowadzenie komunikatu o możliwości przesiadki na inny środek transportu. Pasażerowie chcieliby również wprowadzenia komunikatów informujących o zmianach w rozkładach jazdy, zmianach trasy itp. Co ciekawe, ponad 120 badanych uważa, że konieczne jest wprowadzenie tablic „,choinek” znanych z komunikacji miejskiej w Łodzi $\mathrm{z}$ informacją na temat przebiegu trasy pociągu (wykres 12).

W kwestii oceny siatki połączeń na trasie między Łodzią a Justynowem ankietowani są podzieleni na trzy główne grupy: a) pasażerów, którym siatka połączeń odpowiada, b) pasażerów, którzy nie mają zdania na ten temat, oraz c) pasażerów, dla których obecny kształt połączeń jest nie do zaakceptowania z powodu braku bezpośrednich połączeń z innymi stacjami na terenie Łodzi (wykres 13). Prawdopodobnie ta ostatnia grupa respondentów korzysta ze stacji położonych poza trasą pociągów do Justynowa.

Bogata oferta taryfowa ŁKA przełożyła się na zróżnicowanie kupowanych biletów. Największą grupę stanowią pasażerowie korzystający z Migawki² oraz WBA (wykres 14).

2 Migawka to bilet okresowy uprawniający do przejazdu komunikacją miejską oraz pociągami ŁKA i POLREGIO na terenie Łodzi. 


\section{Elementy informacji pasażerskiej ŁKA wymagające poprawy}

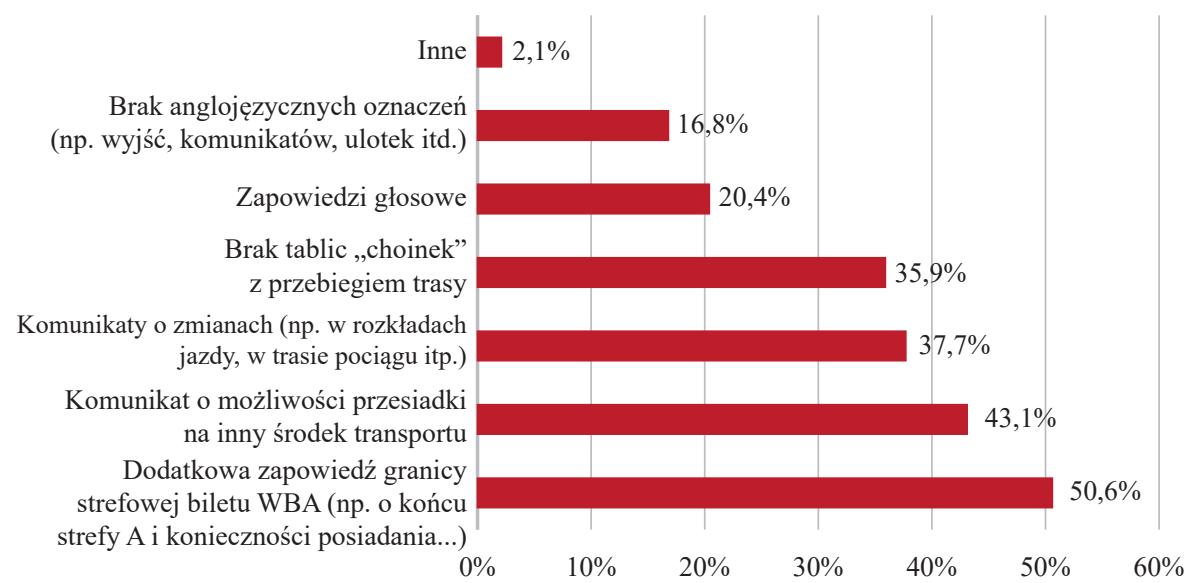

Wykres 12. Elementy informacji pasażerskiej ŁKA wymagające poprawy

Źródło: opracowanie własne.

\section{Ocena siatki połączeń na trasie Łódź-Justynów}

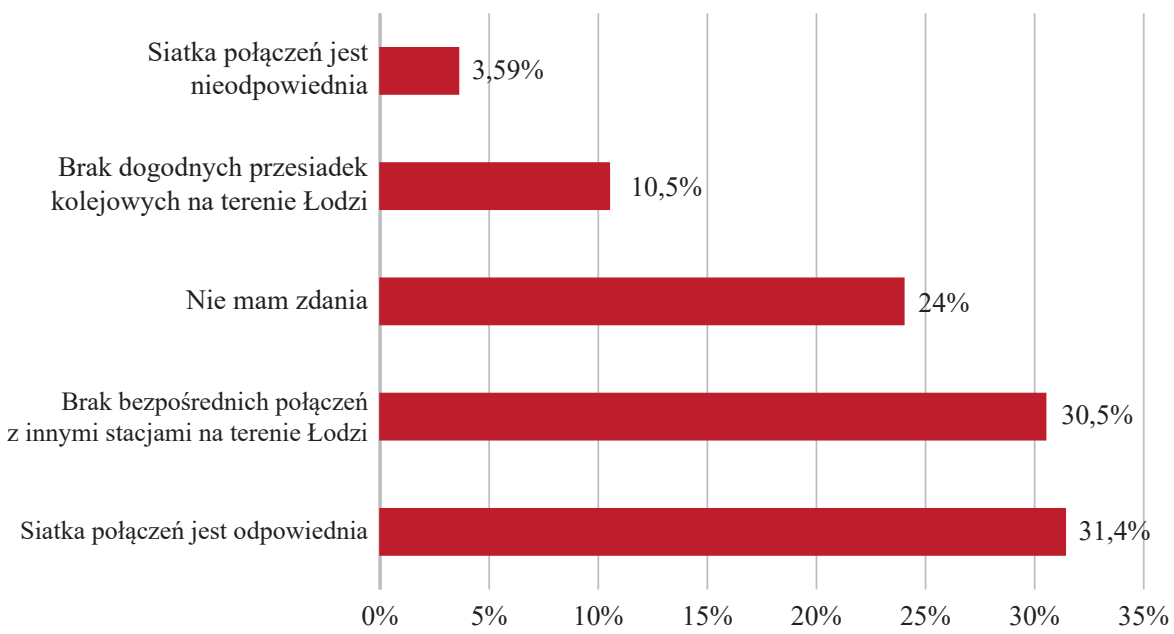

\section{Wykres 13. Ocena siatki połączeń na trasie Łódź-Justynów}

Źródło: opracowanie własne. 
Rodzaj wykorzystywanego biletu

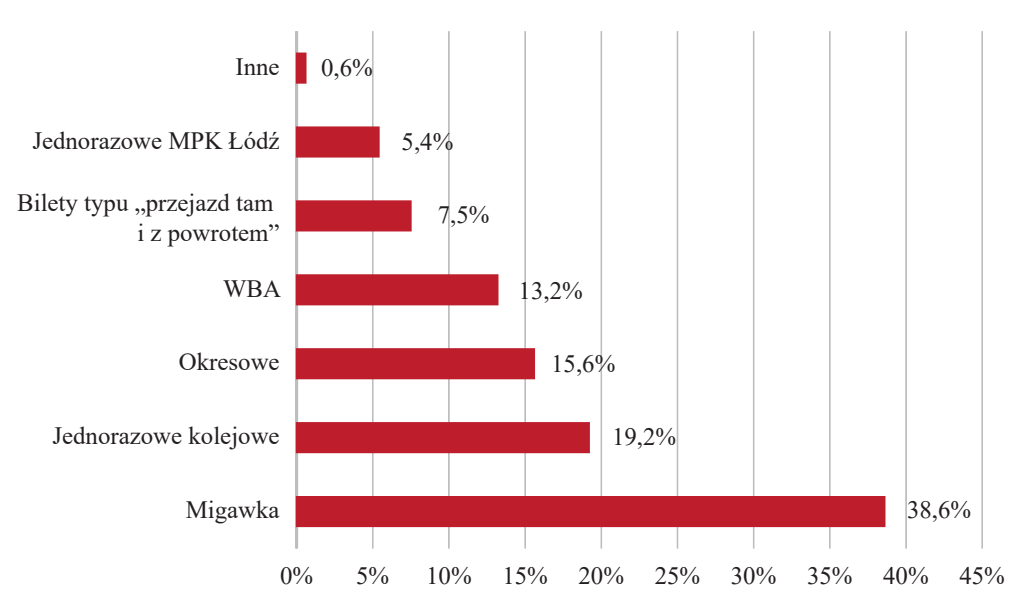

Wykres 14. Rodzaj wykorzystywanego biletu podczas podróży ŁKA na trasie Łódź-Justynów Źródło: opracowanie własne.

\section{Podsumowanie}

Analizując wyniki przeprowadzonego badania, należy zauważyć silną korelację między sposobami zarządzania koleją a satysfakcją podróżnych $\mathrm{z}$ oferowanych usług. Odpowiednie realizowanie procesów zarządczych, w tym w szczególności organizowanie i planowanie, przekłada się na podnoszenie poziomu satysfakcji pasażerów, co w istocie zwiększa prawdopodobieństwo wyboru w przyszłości kolei zamiast innych środków transportu. Respondenci badania wyraźnie wskazali, jakie aspekty, czynniki i cechy są dla nich najważniejsze podczas wyboru kolei jako środka lokomocji.

Zarządzanie transportem zbiorowym jest zadaniem bardzo odpowiedzialnym. Jedynie sprawne prowadzenie tego procesu może zapewnić zaspokojenie potrzeb podróżujących przy spełnieniu zasady zrównoważonego rozwoju oraz rentowności spółki. Wymaga to od kadry zarządzającej odpowiedniej wiedzy, kompetencji oraz zdolności rozpoznania najistotniejszych uwarunkowań funkcjonowania przedsiębiorstwa.

W niniejszej pracy zostały omówione zagadnienia podstawowe. Każda osoba, która planuje mieć styczność z procesem zarządczym w ruchu kolejowym, powinna się z nimi zapoznać. Przedstawione informacje są dynamiczne i prawdopodobnie w krótkiej perspektywie powinny być rozpatrywane przez pryzmat 
zmieniających się cech znamiennych dla kolejnictwa, takich jak rodzaj pojazdów, popyt na przewozy, infrastruktura itp.

Dalszy rozwój kolei aglomeracyjnych i regionalnych będzie wymagał dokonywania niezbędnych inwestycji i ciągłego podnoszenia jakości oferowanych usług. Jednakże są to działania, które przełożą się na wzrost integracji społecznej, przyczynią się do budowania kapitału społecznego oraz rozwoju społeczno-gospodarczego.

Kolej jest gałęzią transportu, która w sposób szczególny i komfortowy umożliwia poruszanie się. Podjęte w aglomeracji łódzkiej działania przełożyły się na wzrost konkurencyjności przewozów kolejowych, a tym samym podwyższanie jakości transportowej. W przypadku ŁKA dużym wyzwaniem zarządczym będzie dalszy rozwój spółki w celu poprawienia dostępności dla całego regionu. Jest to zadanie kapitałochłonne i wymagające znaczących inwestycji.

\section{Bibliografia}

BDL GUS [Bank Danych Lokalnych, Główny Urząd Statystyczny] (2020), https://bdl.stat. gov.pl/BDL/dane/podgrup/tablica [dostęp: 25.06.2020].

Ekologia.pl (2021), Definicja pojęcia: aglomeracja miejska, www.ekologia.pl,https://www. ekologia.pl/wiedza/slowniki/leksykon-ekologii-i-ochrony-srodowiska/aglomeracja-miejska [dostęp: 7.03.2021].

Elżanowski M., Maciołek M.,Przybysz P.M.(1990), Regionjako instytucjaprawnoustrojowa, „Państwo i Prawo”, 8.

UIC Code 406, Capacity, 2nd edition, UIC International Union of Railways, France, 2013 [w:] M. Jacyna, P. Gołębiowski, M. Krześniak, J. Szkopiński (red.), Organizacja ruchu kolejowego, PWN, Warszawa 2019.

Jacyna M., Gołębiowski P., Krześniak M., Szkopiński J. (red.). (2019), Organizacja ruchu kolejowego, PWN, Warszawa.

Kostelecka A., Kulpa T. (2016), Warszawskie Badanie Ruchu 2015 wraz z opracowaniem modelu ruchu. Synteza, https://transport.um.warszawa.pl/sites/default/files/WBR\%20 2015\% 20SYNTEZA\%20POL.pdf [dostęp: 17.03.2021].

Krych A., Kaczkowski M. (2010), Stownictwo kompleksowych badań i modelowania potoków ruchu, II Ogólnopolska Konferencja Naukowo-Techniczna: Modelowanie podróży i prognozowanie ruchu, Kraków, „Zeszyty Naukowo-Techniczne Stowarzyszenia Inżynierów i Techników Komunikacji w Krakowie. Seria: Materiały Konferencyjne”, 94 (153).

Krzemieniecki A., Tarantowicz D. (1975), Mierniki eksploatacyjne w kolejnictwie, Wydawnictwa Komunikacji i Łączności, Warszawa.

Kubalski J. (1968), Komunikacja autobusowa. Ekonomika i eksploatacja, Wydawnictwa Komunikacji i Łączności, Warszawa.

Łódzka Kolej Aglomeracyjna (2018), Raport Roczny 2018, https://ka.lodzkie.pl/_data/Dokumenty/Taryfa/2019/\%C5\%81KA_Raport\%20Roczny_2018.pdf [dostęp: 17.03.2021]. Markowski T. (1999), Zarzadzanie rozwojem miast, PWN, Warszawa. 
Podolski J. (1985), Transport $w$ miastach, Wydawnictwa Komunikacji i Łączności, Warszawa.

UTK [Urząd Transportu Kolejowego] (2014), Formularz sprawozdania, http://utk.gov.pl/ download/1/9183/P-2014.xlsx [dostęp: 7.03.2020].

Wyniki WBR [Warszawskiego Badania Ruchu] 2015 (2016), http://transport.um.warszawa.pl/ warszawskie-badanie-ruchu-2015/wyniki-wbr-2015 [dostęp: 17.03.2021].

\section{Akty prawne}

Ustawa z dnia 26 czerwca 1974 roku Kodeks pracy, t.j. Dz.U. 2020, poz. 1320 ze zm.

Ustawa z dnia 20 czerwca 1992 roku o uprawnieniach do ulgowych przejazdów środkami publicznego transportu zbiorowego, t.j. Dz.U. 2018, poz. 295.

Ustawa z dnia 5 czerwca 1998 roku o samorządzie województwa, t.j. Dz.U. 2020, poz. 1668.

Ustawa z dnia 16 listopada 2006 roku o świadczeniu pieniężnym i uprawnieniach przysługujących cywilnym niewidomym ofiarom działań wojennych, t.j. Dz.U. 2020, poz. 684.

Ustawa z dnia 16 grudnia 2010 roku o publicznym transporcie zbiorowym, t.j. Dz.U. 2020, poz. 1944. 